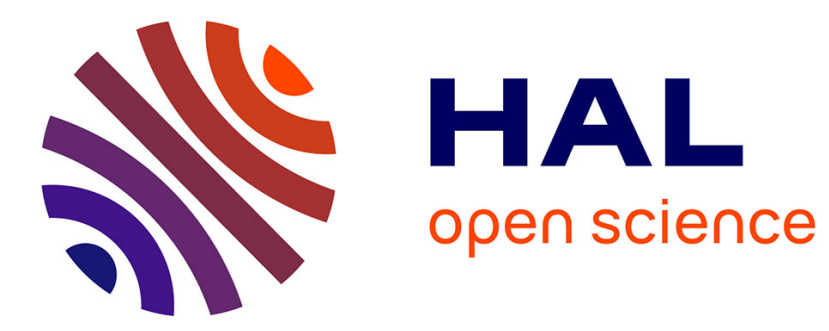

\title{
Possessive voice in Wolof: A rare type of valency operator
}

Sylvie Voisin

\section{To cite this version:}

Sylvie Voisin. Possessive voice in Wolof: A rare type of valency operator. Jan Wohlgemuth; Michael Cysouw. Rara \& Rarissima. Collecting and interpreting unusual characteristics of human languages, 46, de Gruyter, pp.377-400, 2010, Empirical approaches to language typology, 978-3-11-022854. 10.1515/9783110228557.377. hal-03205900

\section{HAL Id: hal-03205900 https://hal.science/hal-03205900}

Submitted on 22 Apr 2021

HAL is a multi-disciplinary open access archive for the deposit and dissemination of scientific research documents, whether they are published or not. The documents may come from teaching and research institutions in France or abroad, or from public or private research centers.
L'archive ouverte pluridisciplinaire HAL, est destinée au dépôt et à la diffusion de documents scientifiques de niveau recherche, publiés ou non, émanant des établissements d'enseignement et de recherche français ou étrangers, des laboratoires publics ou privés. 


\title{
Possessive voice in Wolof: A rare type of valency operator
}

\author{
Sylvie Voisin-Nouguier
}

\section{Introduction}

The purpose of this paper is to describe an uncommon valency operator in Wolof, the verbal morpheme - $l e$ which encodes a possessive relation between the subject and the object of a derived verb. After a brief presentation of background information to facilitate the discussion, internal possessive constructions in Wolof will be presented. First, the particularities of the "leconstruction" will be compared to different strategies of external possession construction observed in different languages following the typology proposed by Payne and Barshi (1999). Second, the "le-construction" will be compared to the Japanese possessive passive, as well as to double derivation constructions, such applicative-passives in other languages. Finally, even if the possessive construction -le in Wolof, and external possession constructions or derivations including passive share some characteristics, I will conclude that this valency operator in Wolof is specific and will propose a hypothesis of its emergence.

\section{Wolof: background information}

Wolof $^{1}$ is a West Atlantic language spoken in Senegal and also in Gambia and Mauritania. Like many Niger-Congo languages, Wolof has a nominal class system. It is reduced in comparison with other Atlantic languages. It is composed of 8 consonants for singular and 2 consonants for plural:

- singular: $b$-, $k-, l-, w-, m-, g-, s$ - and $j-$

- plural: $\quad y$ - and $\tilde{n}$ -

In this system, the consonants are used as support for determinant markers and can't be analyzed as affixed class markers ( *ñ-góor; góor $\tilde{n}-i$ 'the men'; góor ñ-ale 'these men').

Wolof has also a complex verbal inflexion system, including focus marking (Subject Emphatic, Verbal Emphatic and Object Emphatic). 


\section{Sylvie Voisin-Nouguier}

The distinction between subjects and objects (without any distinction between transitive and intransitive subjects) involves contrasts in both constituent order (relatively rigid SVOX constituent order) and indexation of arguments in the verb form, but no case contrast. There is no class concordance between the nuclear function and the corresponding clitics. The subject clitics are combined with tense-aspect-mood morphemes and the object clitics have the following forms:

Table 1. Object clitics

\begin{tabular}{llll}
\hline $1 \mathrm{~S}$ & $m a$ & $1 \mathrm{P}$ & $\tilde{n} u$ \\
$2 \mathrm{~S}$ & $l a$ & $2 \mathrm{P}$ & leen $^{2}$ \\
$3 \mathrm{~S}$ & $k o$ & $3 \mathrm{P}$ & leen \\
\hline
\end{tabular}

The system of verb suffixes coding valency changes is complex. Verbal suffixes encoding valency changes are:

Table 2. System of valency changes

\begin{tabular}{ll}
\hline medio-passive & $-u$ \\
causative & $-e,-a l,-l e,-l u,-l o o$ \\
applicative & $-e,-a l$ \\
co-participative & $-e,-$,oo, -ante, -andoo, -aale \\
antipassive & $-e$ \\
possessive & $-l e$ \\
\hline
\end{tabular}

This system of valency alternations calls for some remarks. First, notice that a passive derivation is missing in this inventory. Second, Wolof includes in its system a derivation -le that I call possessive. This suffix will be detailed in the following sections. Third, even if most of these derivations are common cross-linguistically, Wolof uses different markers for encoding the same valency modifications: the causative is expressed by five different markers, the applicative by two and the co-participative by five. In each voice alternations, the particular suffixes are specialized either for different meanings, or for different verbal classes.

For example, causative suffixes can be divided in two classes of derivation according to verbal classes: (i) $-e$ and $-a l$ for intransitive verbs, (ii) -loo, $-l u$ and $-l e$ for dynamic ${ }^{3}$ verbs. But, in these sub-classes, each morpheme has a 
specific meaning, so the values of causation are different and the syntactic structures of the causative proposition may also be different.

The suffix $-e$ is a lexicalized causative suffix for some unergative ${ }^{4}$ verbs, like génn 'go out (intr.)' vs. génn-e 'go out (tr.)' and some inaccusative verbs, like aay 'be forbidden' / aay-e 'forbid'. The derivation - al is a very productive causative derivation. It is compatible with all unaccusative verbs for product transitive causative counter-parts like bax 'be boiled' / bax-al 'to boil', wex 'be white' / wex-al 'to whiten'. The suffix -loo is the most common causative derivation. It is used with unergative and transitive verbs with an indirect causative meaning. The suffix -lu is used only on transitive verbs. It introduces a new argument, the causer, in subject position, but this derivation also deletes the causee. In other words, the -lu suffix has a double effect on the valency of the derived verb: an augmentation in subject position (causer) and a reduction in object position (the former subject, the causee). Thus, the result of this derivation on transitive verbs is a transitive verb with new grammatical relations. In (1a), naw 'to sew up' has an agentive subject keen and a theme object mbubb. When it is derived with the suffix $-l u(1 \mathrm{~b})$, the subject is the causer of the event and the theme is the object, but the former subject (the causee / agent) can't appear (1c). In some sentences, the whole construction has a specific meaning, the causer is perceived as being the beneficiary of the event.

a. Kenn ñaw-agul mbubb mi. nobody sew.up-NEG3S booboo DEF

'No one has sewn the booboo yet.'

b. Dama-y ñaw-lu roob. EV1S-INACC sew.up-CAUS dress

'I am making sew up the dress.' (or: 'I am getting the dress sewn)'

c. *Dama-y ñaw-lu roob ci/ak Mamadou.

'I am making sew up the dress by Mamadou.'

The last suffix, the causative -le combines with unergative verbs and transitive verbs. It introduces a new argument in subject position. This derivation has a cross-linguistically unusual meaning, forming exclusively an associative causation. Traditionally, causative derivation is divided into two semantics groups: direct and indirect causation. Shibatani and Pardeshi (2001) show that these meanings constitute a semantic continuum, where the socalled associative meaning is an intermediary sense between direct causation and indirect causation. Associative causation is more frequently conveyed by 
a causative morpheme also coding direct or indirect causation. But, in some languages like Wolof, this meaning has its own dedicated marker.

a. Tabax naa kër-am. build P1S house-POSS3S

'I built his house.'

b. Tabax-le naa ko kër-am. build-CAUS P1S O3S house-POSS3S

'I helped him build his house.'

Note that the causative derivation -le is different from the possessive $l e$ derivation presented in this study. In possessive $l e$-construction, the possessive relationships are not marked, they don't used a specific morpheme or a possessive marker. Whereas in causative -le, if there is a possessive relationship between two entities, possession is obligatorily marked by the internal possessive marker. Without this marker, the possession is not clear. For example, Tabaxle naa ko kër gi means 'I helped him build the house'; the house can be possessed by me, by him or by somebody else.

Thus, each causative suffix has a particular effect, and the specific meaning is linked to particular verbal classes. In Table 2, when several suffixes are listed to encode a same syntactic operation of valency change, note that some semantic differences are involved, like we come to demonstrate for the several causative suffixes. This also shows the complexity and the richness of the verbal derivation system of this language. In some cases a diachronic hypothesis can be made for the emergence of this plurality of forms, but synchronically these derivations all co-occur. Evidence for a diachronic hypothesis can be observed in co-occurrence patterns. Compounded suffixes can be used on a verbal class, but each component derivations that make up the compound can't be used alone on this class of verb. For example, the derivation -lu is presented by Church (1981) as the fusion of an applicative derivation - al and the medio-passive derivation $-u$.

"Sur le plan formel, ce suffixe résulte vraisemblablement de la combinaison de $-a l_{3}$ bénéfactif et de $-u_{3}$ réfléchi. Cependant la voyelle $a$ n'est jamais présente : on dit ràbblu 'faire tisser pour soi', et non *ràbbalu. Ce suffixe [-lu] diffère du $-a l_{3}$ en ce que le bénéficiaire est sous-entendu; dinaa $\left({ }^{*}\right.$ ma $)$ beylu sama tool 'je ferai cultiver mon champ (pour moi)'." (Church 1981: 287)

[On the formal aspect, this suffix probably results from the combination of the benefactive $a l_{3}$ and the reflexive $-u_{3}$. However, the vowel a is never conspicuous: we say ràbblu 'to make weave for himself', and not *ràbbalu. This suffix $[-l u]$ dissent from $-a l_{3}$, in that the beneficiary is implied; dinaa (*ma) beylu sama tool 'I will make grow my field (for myself).'] 
The applicative derivation - $a l$ adds a beneficiary object (4). On this new derived verb, the adjunction of medio-passive $-u$ involves the deletion of the agent participant (the subject) and the promotion of the beneficiary to subject function, leading at the same time to the interpretation of the subject as the initiator of the event (5).

(3) Sàmba tabax na kër gi. Samba build P3S house DEF

'Samba built the house.'

(4) Sàmba tabax-al na Waly kër gi. Sàmba build-APPL P3S Waly house DEF

'Sàmba built the house for Waly.'

(5) Waly tabax-al-u na kër gi. (tabax-al-u>tabax-lu) Waly build-APPL-MDP P3S house DEF

'Waly has got the house built.'

The meaning of this double derivation has been reinterpreted with a causative signification, described sometimes as a benefactive-causative. This composition can only be conceived of as the result of a diachronic process.

\section{Possessive constructions}

In Wolof, a possessor-possessum relationship can be expressed, as in other languages, by different strategies. Possession is built with the possessive lexical predicate am 'have' (6), moom 'to own' (7) and yor 'to have with oneself' (8).

(6) Moo am xale.

ES3S have child

'She has a child.'

(7) $\mathrm{Ku}$ moom fas wii

INTER own horse DEM

'Who owns this horse?'

(8) Su yor-oon caabiji, jox ma ko.

HYP have.with-PAS key DEF give O1S O3S

'If he had the key with him / on him, he would have given it to me.' 
Moom and yor are used essentially for alienable possession, while am conveys both alienable and inalienable possession, Am na kër yu bare 'He has several houses'; Am na ñetti doom 'He has three children'.

Possessive predicates can combine with the suffix $-e$. The derivational $-e$ morpheme present on these verbs is not productive; it operates only with possessive predicates. It doesn't change the argument structure, but introduces a temporary possession.

(9) Mën-ul ñów, moo am-e xale bi. can-NEG3S come ES3S have-e child DEF

'She can't come, she is the one who has the child.'

Possession can also be expressed by a genitive construction, as illustrated in (10) or by a possessive determiner (cf. Table 3).

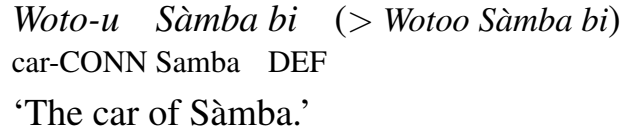

Table 3. Possessive determiner

\begin{tabular}{llll}
\hline sama woto & 'my car' & suñu woto & 'our car' \\
sa woto & 'your car' & seen woto & 'your car' \\
woto-am $>$ wotoom & 'his / her car' & seen woto & 'their car' \\
\hline
\end{tabular}

Against this background, we now turn to the possessive -le construction, the main topic of this paper. The derivation -le involved in this construction is included in the voice system and the features of the construction lead us to connect it to external possession constructions.

\section{Possessive derivation}

The verbal possessive marker -le is a valency-changing suffix. It increases the argument structure of the verb. Appearing on an intransitive verb, it derives a transitive verb with the following argument structure:

- an additional argument with the semantic role of possessor is introduced in the subject position; 
- the object of the derived possessive verb cumulates the role of possessum, and the semantic role assigned to the subject in the non-derived construction.

a. Woto bi gaaw na.

'The car is fast.'

b. Sàmba gaaw-le na woto.

Sàmba be.fast-POSS P3S car

'Sàmba has a fast car.'

c. Sàmba moo ko gaaw-le.

Samba ES3S O3S be.fast-POSS

'Samba has a fast one.'

In example (11a), the subject is a patient/theme argument of which a state is predicated by the monovalent verb gaaw 'to be fast'. In (11b), the same verb gaaw contains an additional morpheme, the suffix -le. The same participant woto bi occurs with the same semantic role of patient. However, a new argument Sàmba is introduced in the sentence. Thus, the derivation le changes the grammatical relations. The patient-subject woto is demoted to object position and shares all the features of an object, e. g. it can be pronominalized with $k o(11 \mathrm{c})$. The object woto receives an additional meaning of possessum. Sàmba is the new argument introduced in the subject position, and its semantic role is possessor. It can't be regarded as the agent, as it has no effect on the state of the patient woto.

The valency-increasing effect of the derivation -le differs from causative and applicative markers, which constitute the commonest types of valencyincreasing operators. Sàmba in (11b) is not a causer, as is the new argument added by causative derivation. Even if the system of voice in Wolof also has a causative suffix -le, this causative derivation has an associative semantics, as we have seen in example (2a) on page 380. Moreover, woto, in example (11b), is neither a beneficiary, nor a comitative, nor an oblique argument promoted as the object of a clause, as it is the case in applicative constructions.

Returning to the features of the possessive construction with -le, we can also remark that the possessive relation between the two arguments of the derived verb does not involve any possessive morphology. Thus, the derivation -le builds a possessor-possessum relationship without specific possessive morphology, except the suffix -le itself. 
This derivation is only possible with a limited class of intransitive verbs that can be characterized as unaccusatives, since a common feature of all those verbs compatible with the possessive -le is the non-agentivity of the subject. However, although most unaccusative verbs accept this marker, -le seems to be more productive with verbs expressing quality, e. g. rafet 'be beautiful', dee 'be dead, die', baax 'be good' etc.

Baax-le na ay téeré.

be.good-POSS P3S INDEF book

'He has good books.'

(13) Góor gii, moo dee-le jabar.

man DEM ES3S die-POSS wife

'This man's wife is dead. (This man became a widower.)'

(14) Maa réer-le xar.

ES1S be.lost-POSS sheep

'I lost my sheep. (I'm the one who lost a sheep.)'

\section{External possession constructions and other possessive constructions}

The features of -le constructions can be compared with so-called external possession, i.e.

"[...] constructions in which a semantic possessor-possessum relation is expressed by coding the possessor (PR) as a core grammatical relation of the verb and in a constituent separate from that which contains the possessum (PM)." (Payne and Barshi 1999: 3).

If we look again at the example (11), repeated in (15), the possessor Sàmba - the subject - and the possessum woto 'car' - the object - are two distinct constituents, treated as nuclear arguments of the verb gaaw-le.

(15) Sàmba gaaw-le na woto.

Sàmba be.fast-POSS P3S car

'Sàmba has a fast car.'

However, even though the construction of Wolof possessive verbs shares some features with the possessor-possessum relation described by Payne and Barshi in the external possession construction (EPC), it is nevertheless distinct from the different strategies of external possession found crosslinguistically. In their typology, Payne and Barshi (1999) describe four different strategies: 
- incorporation;

- possessor raising;

- applicative voice;

- External possession construction without any morphological marker, including the so-called "double unaccusative" in Sinitic languages

\subsection{Incorporation}

In external possession constructions with incorporation, such as in Guaraní (example 16), the possessor is encoded as the subject of the clause and the possessum is incorporated in the verb.

(16) Guaraní (spoken in Paraguay, Velázquez-Castillo 1999: 78)

a. Che akã-jere.

1INACT head-turn

'To me turns head' = 'I'm dizzy'

b. Hetymã-po'is

3INACT=leg-thin

'(S)he had the legs thin (= thin legs)'

\subsection{Possessor raising}

The term "possessor raising" or "dative construction" is commonly used for dative clitic constructions in Romance languages, such as French (17), Spanish (18) and Romanian (19). In Romanian, we can see that "dative constructions" are not restricted to inalienable possession. In this construction, the possessor is an argument of the verb distinct form the possessum. In French (17), the possessor vous 'you' is the dative argument and the possessum the object argument of the verb couper 'cut'.

(17) French

Il vous coupe les cheveux.

'He cuts your hair.'

(18) Spanish

Me da vueltas la cabeza.

'To me turns head.' = 'I'm dizzy.' 
(19) Romanian (Timoc-Bardy 1996: 242)

$\hat{I} i \quad$ pleac trenu-l

(he) him leave train-the

'His train is leaving.'

\subsection{Applicative voice}

External possession constructions can also be found in applicative clauses. In some languages, the applicative derivation does not require an internal possessive marker, as in Mohawk (20). In other languages, an internal possessive marker must encode the possessive relationship between the two nuclear arguments, cf. example (21a).

(20) Mohawk (Baker 1999: 293)

Wa-hi-'sere-ht-óhare-'s-e'.

FACT-1SG:SUBJ/MASC:SG:OBJ-car-NOM-wash-BEN-PUNC

'I washed his car.' (better: 'I washed the car for him.')

(21) Oluta Popoluca (Zavala 1999: 340)
a. $\phi=? o: k-u=k$
tan=majaw.
$\mathrm{B} 3(\mathrm{ABS})=$ die-CMPL=ANIM A1(POSS) $=$ wife

'My wife died.'

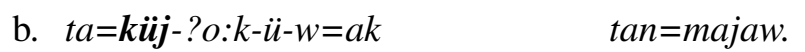

B1(ABS)=APPL2-die-INV-CMPL=ANIM A1(POSS $)=$ wife

'My wife died on me.' (or: 'I got affected by the fact that my wife died.').

In Wolof, the applicative derivation can be linked to possession relationship. With transitive verbs, the applicative marker -al adds a new object. When this object is a beneficiary, it can be the possessor of the "patient" object. Nevertheless, in this case, as in Oluta Popoluca, the possessor-possessum relationship must be expressed by an internal possessive marker, the possessive determiner sama 'my' (22).

(22) Mamadu seet-al na ma sama jabar.

mamadou look.for-APPL P3S 1S POSS1S wife

'Mamadou looked for my wife for me.' 
5.4 External possession constructions without morphological strategy and "double unaccusative"

External possession construction without morphological marking is the last strategy. It presents many similarities with the -le constructions. In some languages, monovalent verbs can have a transitive structure with a meaning of possession without resort to any particular morphology.

In Ilkeekonyokie (a dialect of Maasai), the subject encoded by the prefix áa- must be interpreted as the possessor of the object entitó 'girl' (23a). This possessive interpretation is induced only by the transitive use of monovalent verbs. Payne and Barshi (1999: 4) point out that, in this language, all monovalent verbs (derived or not) can appear in this type of construction.

(23) Maasai, Ilkeekonyokie dialect (Payne and Barshi 1999: 4)

a. áa-yshú en-titó.

3>1-be.alive FEM.SG-girl.NOM

'My girl is alive (with presumably positive effect on me).'

b. k-áa-ból ol-páyyàn $\varepsilon n$-kưtứk.

DSCN-3>1-open MASC.SG-man.NOM FEM.SG-mouth.ACC

'The man will open my mouth.' (lit.: 'The man will open me the mouth.')

These external possession constructions share some features with -le constructions. There is no internal possessive morphology and these constructions are restricted to monovalent verbs. But they differ by the absence of restriction to a specific verbal class, and by the absence of verbal derivation.

"Double unaccusative" constructions in Sinitic languages are also reminiscent of the Wolof constructions. Hilary Chapell (1999: 205) notes that 'double unaccusative' constructions are restricted to unaccusative verbs. ${ }^{5}$ She describes this construction as syntactically "aberrant":

"[...] syntactic construction where the rules of grammar, narrowly understood, are violated: in the double unaccusative, intransitive process verbs take two arguments, one more argument than the verb valency should allow. [...]

The two arguments of the intransitive verb designate possessor and possessum.” (1999: 195)

(24) Taiwanese Southern Min (Chapell 1999: 204)

I pái tioh tò-kha. 3SG lame PRES left-leg 
'He has gone lame in the left leg.'

Cantonese Yue (Chapell 1999: 207)

$\mathrm{Kui}^{5} \mathrm{Sei}^{2} \mathrm{joh}^{2}$ taai $^{3}$ taai $^{2}$.

3SG die PERF wife

'He was bereaved of his wife.' (lit.: 'He died wife.')

Thus, as is the case with the le-construction in Wolof, the two arguments of the clause are in the syntactic position of subject and object. Subject and object arguments are respectively, the possessor and the possessum. But, contrary to the Sinitic and Maasai languages, in Wolof, the possessive constructions are not syntactically 'aberrant' because they are morphologically marked by $-l e$. The external possession $l e$-construction, in distinction to all strategies described, shows a specific morphology.

Now, the question is what kind of marker is this morpheme? Can we see in the -le suffix a complex verbal derivation which, in particular conditions, for example with unaccusative verbs, would take on a possessive interpretation, as found in some languages with passive voice?

5.5 External possession resulting from passive voice or applicative-passive derivation

In this section, two uses of passive derivation in different languages will be examined: a) a specific use of the -(r)are suffix in Japanese, sometimes called the possessive passive or adversity passive, and b) a double derivation with the passive, similar to the applicative-passive derivation in Tswana.

In the possessive passives in Japanese, the passive derivation does not have its canonical function and this specificity allows possessive interpretations.

\subsubsection{Non-canonical voice strategy: the possessive passive in Japanese}

When the passive suffix -(r)are is used with unaccusative verbs, a possessive relationship is established between the subject of the passive clause and the dative argument (prior subject) or affected relationship.

(26) Japanese (Gunji 1987: 63-64)

a. Tomio-wa Susan-ni keimusyo-ni ik-are-zunisun-da. tomio-TOP susan-DAT jail-to go-PASV-do.without-PAST

'Tomio was not adversely affected by Susan's going to jail.' 


\section{b. Susan-wa Noami-ni nak-are-ta.} susan-TOP noami-DAT cry-PASV-PAST

'Susan was adversely affected by Noami's crying.'

\subsubsection{Double derivation: applicative-passive constructions}

In Tswana, a double applicative-passive derivation on intransitive verbs produces an intransitive clause with an oblique argument introduced by $k e$ 'by'. With some verbs, a possessive relationship is established between the subject and the oblique.

\section{(27) Tswana (Creissels, p.c.)}

\section{Batho ba shelwa ke mantlo.}

2people SC2 burn.APPL.PSV by 6house

'People's houses are burning.'

To summarize, on the one hand the le-construction in Wolof presents features of external possession construction. There is no internal possessive marker in the clause. The possessor and the possessum are in different nuclear argument positions, respectively subject and object. The best syntactic test revealing that the possessum is an object in Wolof is pronominalization (cf. (11)); recall that there is no passive derivation in this language. The restriction on intransitive verbs connects the le-constructions to the "double unaccusative" (Sinitic languages) and external possession construction without a morphological strategy (Maasai). But the verbal derivation -le in Wolof removes this construction from strategies of external possession construction, since the verbal derivation -le is not an applicative marker. ${ }^{6}$ On the other hand, the comparison with the possessive passive of Japanese and double applicative-passive derivation of Tswana shows that possessive relationship between different arguments of the clause can be produced by passive or compound derivation. But in this case, the linking between grammatical relations and the pair possessor-possessum is different from that occurring in le-construction. In Japanese, if the possessum is an accusative/object argument, the possessor is a subject/ dative. In Tswana, the possessor has the subject function, but the possessum is demoted to oblique by passive derivation. Moreover, the absence of passive derivation in Wolof has been pointed out and the -le suffix can't be related to the medio-passive derivation $-u \sim-k u$. Even though a synchronic passive derivation is absent in Wolof, a hypothesis of complex derivation will be developed in the next section. 


\section{Evolutional hypothesis of the -le morpheme}

The comparison with possessive passive and applicative-passive constructions leads us to consider the present form -le, in Wolof, as the possible result of the grammaticalization of a double applicative-passive derivation. But, synchronically, the fact that Wolof does not have a passive derivation makes it impossible to analyze the valency change encoded by the possessive suffix as a combination of applicative and passive, as seems to be the case in Tswana. A plausible diachronic explanation however is that Wolof possessive -le results from the grammaticalization of a complex marker where the second marker is $*_{-} e$, at a stage of evolution when passive in Wolof was coded by a suffix $*-e$.

\subsection{Passive derivation in Atlantic languages}

Doneux and Podzniakov (p. c.) have reconstructed a suffix * $-i$ in Proto-Atlantic as a passive derivation. In some Atlantic languages, for example in different dialects of Diola, the reflex is $-i$ (see Sapir (1965) for Diola-Fogny and Bassène (2006) for Diola-Banjal).

(28) Diola-Banjal (Bassène 2006: 226)

a. Atejo na-jug-e figen si-bé sasu. Atéjo s3s-see-TAM yesterday CL4-cow CL4.DEM4

'Atéjo has seen the cows yesterday.'

b. si-bé sasu su-jug-i figen. CL4-cow CL4.DEM4 CL4-see-PSF yesterday

'The cows have been seen yesterday.'

In other languages like Singandum (a dialect of Sereer), Buy or Peul, the passive suffix is $-e .^{7}$ All of these languages are classified in the North Branch of the Atlantic family, as is Wolof.

(29) Peul, dialect spoken in East-Niger (Labatut 1982)

a. ngelooba monn-at Iisa. camel annoy-TAM Iissa

'The camel is annoying Iisa.'

b. Iisa monn-ete.

Iisa annoy-TAM.PASSIVE

'Iisa is being annoyed.' 
So, the existence of a passive derivation $-e$ in an earlier period in Wolof is conceivable. Some traces of this derivation are maintained in Wolof. For example we have already seen one derivation $-e$, which is specific to the possessive verbs and encodes temporary possession, in the same way that ser and estar do in Spanish. Ser is the copula used in possessive construction, but estar can be used to indicate temporary possession; note that estar is also the copula expressing resultative states.

In the system of voices, several derivations involve a reduction of valency or a remodelling of grammatical relations: ${ }^{8}$

Table 4. Suffixes of reduction or remodelling of grammatical relations

\begin{tabular}{ll}
\hline co-participative & $-e,-$ oo $(<* \mathrm{u}-\mathrm{e})$, -ante $(<*$ ant-e $)$, \\
& - andoo $(<*$ ànd-u-e $)$, -aale $(<*$ aal-e $)$ \\
antipassive & $-e$ \\
\hline
\end{tabular}

All of these voice markers include a suffix $-e .{ }^{9}$ Alone, this suffix has two functions: antipassive and reciprocal.

The antipassive (AP) effect occurs with transitive and ditransitive verbs with recipient objects. When these verbs are derived by $-e$, the object / recipient is obligatorily deleted, but this deletion doesn't mean that no recipient is implied in the process; rather, similarly to antipassive in ergative languages, the antipassive derivation conveys a habitual or generic meaning.

a. Xajbi du màtt-e. dog def. ENeg3S bite-AP

'The dog doesn't bite.'

b. *Xaj bi du matte xale yi. The dog doesn't bite the children.

a. Alal du jox-e màqaama. fortune ENég3S give-AP prestige 'Fortune doesn't give one prestige.'

b. *Alal du joxe màqaama sàcc bi.

'Fortune doesn't give the prestige to the thief.'

With naturally reciprocal events as defined by Kemmer $(1993)^{10}$, this derivation has a reciprocal function. The reduction of verbal valency can be observed either through the plurality of the subject (33) or the demotion of the object to an oblique function, see the clitic preposition ag 'with' (34). ${ }^{11}$ 
(32) Lu mu daj, sànni la ko.

REL N3S meet throw O2S O3S

'Anything that he meets, he throws it to you.'

(33) $\tilde{N} u$ daj-e foofuci pénc mi. N1P meet-REC there LOC square DEF

'We meet there at the square.'

(34) $\tilde{N} u$ daj-e=eg ay waxambaane yu takku.

N3P meet-REC-with INDEF comrade CONN be.numerous

'They met up with several comrades.'

The other co-participative derivations also contain -e. Combined with other morphemes, $-e$ produces different meanings such as distributive actions $(-$ andoo $)$, as in (35). ${ }^{12}$

(35) Noo dugg-andoo kàrce. ES1P enter-DISTR army

'We went into the army at the same time.'

This suffix - $e$ corresponds to the Plurality of Relations marker ${ }^{13}$ (PR) described by Lichtenberk (2000) for Oceanic languages. This term refers to a morphological marker which is used to encode reciprocal and certain other situations, but not reflexive situations. These others functions are: chaining, collective, converse, distributed, repetitive, depatientive, middle, kinship relations, and collective plurals. In Wolof, $-e$ encodes reciprocal and depatientive (our antipassive), and with other morphemes:

-ante encodes reciprocal situations with verbs denoting non-naturally reciprocal events,

-andoo encodes simultaneous distributed situations,

-oo encodes non simultaneous collective situations, and

-aale encodes distributed situations.

\subsection{Hypothesis of grammaticalization: $-l e<-a l-e$}

The former section presented a proposal aimed at resolving the problem of the identity of the suffix $-e$ present in the -le possessive marker, given the absence of passive derivation in Wolof. However, the identity of the $-l$ or $-a l$ suffix has not yet been treated. In the presentation of causative markers, it was 
shown that some causative derivations are complex and that this complexity involves a suffix $-a l$, systematically reduced to $-l$ in the compound suffixes (cf. Church's (1981) hypothesis for causative -lu). In the current system of valency changes, two suffixes both have the form -al and the effect of valencyincreasing: a causative and an applicative suffix. Thus, one can ask does the suffix - al contained in the possessive -le derivation result from the causative or the applicative derivation?

To answer this question, several characteristics can be explored. Presenting the $l e$-construction as the result of the grammaticalization of several voice markers entails, on the one hand, explaining the syntactic configuration of the $l e$-construction through a double reorganization of grammatical relations, and on the other hand, providing sound justification for the possessive reinterpretation of the $l e$-construction through voice blending.

For the syntactic configuration of $l e$-constructions, the approach adopted here is that the suffix $-e$ is responsible for the remodelling of grammatical relations and it can have a canonical or non-canonical use as in Japanese, and either the causative or the applicative derivation is responsible for the increasing valence of the intransitive verb.

On one hand, several arguments speak in favour of the applicative derivation. First, only the applicative derivation seems to be related to external possession construction constructions, and this derivation has effects similar to those of the non-grammaticalized double derivations in Tswana and other Bantu languages. Second, Payne and Barshi (1999: 17) note that even if a causative analysis might be suggested,

"the difficulty of a causative analysis [...] is that clear causative morphology is not known to surface in external possession constructions (and to our knowledge, a causative solution for EP has never been proposed in the literature for any language)."

Third, if transitivity of the possessive construction results from the following two operations on valency: augmentation via applicative or causative, and reduction (or remodelling of grammatical relations) via passive (or more specifically in Wolof, by plurality of relations marker), then the possessive meaning is more difficult to explain in the le-construction with causative than with the applicative derivation. Indeed, if something has some quality and, at the same time, someone receives some emotional or psychological effects of this quality, then one possible reinterpretation is that the human being is the possessor of the thing, and the meaning of benefit is more plausibly conveyed by the benefactive applicative than by a causative derivation. 
Since syntactic reorganization with the applicative derivation is obligatorily linked to an verbal augmentation of valency via the addition of a new object, the plurality of relations derivation might be responsible for the promotion of this new object to subject position and consequently the demotion of the former subject. But, this demotion is not correlated with an oblique function, as in the Japanese possessive passive where the possessum has an object function.

a. Woto bi gaaw na. The car is fast.

b. *Woto bi gaaw-al na Sàmba. Applicative derivation The car is fast for Sàmba.

c. Sàmba gaaw-al-e na woto bi. Applicative-PR derivation Sàmba has a fast car.

This is the single plausible reorganization that could explain the subject function of the possessor with applicative derivation. The possessive interpretation is induced from the benefactive meaning of the applicative derivation -al. But, in Wolof applicative derivations are incompatible with unaccusative verbs. Woto bi gaaw-al na Sàmba might mean 'The car has made Samba fast' or something else, but never 'The car is fast for/to Samba'.

Several arguments, on the other hand, speak in favour of a causative derivation playing a role in the system of voice in Wolof. First, there is already one causative suffix -le. This derivation has an associative meaning (cf. example (2)) and it is used only on dynamic verbs. Second, double applicative derivation and the plurality of relations marker with an antipassive function are attested in Wolof with dynamic verbs. We have seen that the use of $-e$, with an antipassive function (cf. (30) and (31)) is possible with verbs having a recipient object, so this derivation is possible with some transitive verbs and is fully productive with ditransitive verbs, in particular with ditransitive verbs derived by means of the applicative marker -al.

a. Togg naa yàpp wi. cook P1S meat DEF

'I have cooked the meat.'

b. Togg-al naa la yàpp wi. cook-APPL P1S O2S meat DEF

'I have cooked the meat for you.' 


\section{c. Togg-al-e naa yàpp wi. (> Toggale naa yàpp wi) cook-APPL-PR P1S meat DEF \\ 'I have cooked the meat (for people).'}

And, as we can see, in this double derivation, the suffix -al keeps its form; it is not reduced to $-l$. Third, the applicative derivation is never compatible with stative verbs; only the causative derivation -al is employed with this verbal class.

\section{a. Woto bi gaaw na.}

The car is fast.

b. Sàmba gaaw-al na woto bi. Causative derivation Sàmba makes the car is fast.

c. Sàmba gaaw-al-e na woto bi. Causative-PR derivation Sàmba has a fast car.

While, syntactically, a double derivation involving an applicative in the le-construction in Wolof is difficult to motivate, a causative derivation is plausible. Semantically, the plurality of relations marker can be responsible for abandoning the direct causative interpretation normally linked with -al causative. Sàmba is reinterpreted as the endpoint of the event and not as the initiator.

\section{Conclusion}

The le-construction shares several features with external possession construction. The possessor and the possessum are in different core arguments of the derived verb, respectively the subject and the object. The possessive relationship established between the subject and the object is expressed only by the verbal derivation -le.

We compared the le-construction to external possession construction strategies. The strategy closest to Wolof is the strategy without morphology (Maasai and Sinitic languages), essentially because the composition of suffix $l e$ is synchronically not clear. It presents the same form as the associative causative -le, but apparently it shares no syntactic and semantic effects with this causative derivation. We also presented two kinds of voice derivation. The possessive passive in Japanese has the particularity to function with intransitive verbs. In this non-canonical use, the passive derivation builds a transitive clause where the two arguments maintain a possessive relationship. In 
Tswana, a double applicative-passive derivation creates the same effect. On this basis, a diachronic hypothesis has been proposed for the verbal derivation -le.

Despite the synchronic absence of passive derivation in Wolof, some remnants of an old passive derivation $*_{-} i$ have been presented. The different functions of this trace lead us to identify it as a plurality of relations marker. Indeed, in its antipassive function, the derivation - $e$ gives a habitual or general meaning of the process, and in this way it conveys the meaning that the process acts the same on every potential recipient. With its reciprocal function, the plurality of relations can be seen in that the relation between the A participant and the $\mathrm{B}$ participant is the same as the relation between the B participant and the A participant. But, with reciprocal function $-e$ needs an added morpheme -ant to function with non-naturally reciprocal events. With other morphemes, the plurality of relations marker encodes collective and distributed actions.

The second morpheme involved in the possessive, -le, has two possible sources: causative or applicative. With respect to strategies of external possession construction and double applicative-passive in Tswana, the applicative derivation should have been preferred. But, for the system of voice in Wolof, it appears more probable that the possessive construction is the counterpart of the associative causative derivation with unaccusative verbs. ${ }^{14}$

To summarize, the possessive marker in Wolof is the result of the grammaticalization of a causative marker - with an associative and direct meaning - and a plurality of relations marker. This diachronic hypothesis explains the syntactic organization of the possessive construction. The causative derivation adds a causer subject, and the theme argument, of which a state is predicated, is demoted to a syntactic object. On this basis, the plurality of relations marker has a remodelling effect on semantic role. The subject is reinterpreted as the endpoint of the event and not as the initiator. Consequently, the causative meaning is lost. The possessive meaning conveyed by the whole construction is perhaps due to the associative meaning sometimes linked with the causative derivation -al. Or, as in the external possession construction strategy without morphology, the possessive relationship can be simply induced by the non-canonical use of unaccusative verbs (i.e. they are used as transitive verbs). Indeed, with the plurality of relation effect, the derived verb is still non-dynamic, and yet has a subject, which presents many features of agent. In the same way, this diachronic hypothesis can explain why, with dynamic verbs, the causative meaning of causative -le ('help, 
assist') is fuzzy. The subject, as in possessive constructions, loses its role of initiator of the action; it is reinterpreted as an associative-agent participant to the process like in the following causative sentence: Sàmba bey-le na ko tool yi 'Sàmba helped him cultivate the fields'. The dynamicity of the verb also involves that the subject is not interpreted as an endpoint participant.

Thus, the particularity of Wolof is to have developed a specific marker for possessive constructions from a causative derivation, and the syntactic configuration of these constructions permits including them into external possession construction. Finally, the absence of such markers in others world languages can be explained first, by the absence of a causative marker in the expression of external possession construction and secondly, the voice system of Wolof. This complexity is not specific to the Atlantic family as a whole but is a language-specific property of Wolof.

\begin{abstract}
Abbreviations
$\mathrm{AP}=$ antipassive $; \mathrm{APPL}=$ applicative $;$ CAUS = causative DEF $=$ definite determiner; DEM = demonstrative; DISTR = distributive marker; ES1S = Subject; Emphatic 1st person singular; ES3S = Subject Emphatic 3rd person singular; EV1S = Verbal Emphatic 1st person singular; HYP = hypothetic; INACC = imperfective (inaccompli); INDEF = indefinite determiner; INTER = interrogative; LOC = locative preposition; $\mathrm{MDP}=$ medio-passive; N3P = Narrative 3rd person plural; N3S = Narrative 3rd person singular; $\mathrm{NEG}=$ negative; $\mathrm{O} 1 \mathrm{~S}=$ object clitic 1 st person singular; $\mathrm{O} 2 \mathrm{~S}=$ object clitic 2 person singular; $\mathrm{O} 3 \mathrm{P}=$ object clitic 3 rd person plural; O3S = object clitic 3rd person singular; $\mathrm{P} 1 \mathrm{~S}=$ perfect 1 st person singular; $\mathrm{P} 3 \mathrm{~S}=$ perfect 3rd person singular; PAS = past tense; $\mathrm{POSS}=$ possessive voice; $\mathrm{POSS} 3 \mathrm{~S}=$ possessive determiner 3rd person singular; $\mathrm{PR}=$ plurality of relation marker; $\mathrm{PRO}=$ pronoun; $\mathrm{REC}=$ reciprocal; $\mathrm{REL}=$ relative marker.
\end{abstract}

\title{
Notes
}

1. The Wolof examples used here are extracted from various sources. The main sources are two dictionaries Wolof-French (Fal, Santos, and Doneux 1990; Diouf 2001) and two story books (Keteloot and Dieng 1989; Kesteloot and Mbodj 1983).

2. The second and the third plural persons present the same form. The subjects clitics for the first and the third plural persons also have the same pronunciation $\left[\mathrm{n}^{\mathrm{j}} \mathrm{u}\right]$, but they are distinguished by two different orthographies, respectively $n u$ vs. $\tilde{n} u$.

3. By dynamic we understand all verbs with an agent subject, both intransitive and transitive. 
4. The notions of unaccusative and unergative are taken from Relational Grammar developed by Perlmutter and Postal (1984) to divide intransitive verbs into two groups: those which have a patient subject are called unaccusative verbs; and those which have an agent subject: unergative verbs.

5. Except for $\mathrm{jau}^{2}$ 'run, leave' in Cantonese.

6. Applicative markers, in Wolof, are $-a l$ and $-e$.

7. In Peul, the passive derivation is combined with tense-aspect-mood markers and presents $-a \sim-e$ variations (Labatut 1982: 270).

8. In some cases voices which have a decreasing effect, such as middle or reciprocal, are described as voices where arguments receive a new syntactic function and this modification of valency involves the reorganization of grammatical relations. But, this kind of description focusses on syntactic effect and hides the semantic aspects of valency changes. In the reciprocal, for example, the reduction of syntactic valency is not correlated with the same reduction in semantic valency. The former object, at the same time that it is promoted to subject function, takes on a new semantic role of agent, but it also maintains its original semantic role of patient. And the former subject, which keeps its syntactic function (subject) and its semantic role of agent, receives a new semantic role of patient. Consequently, this kind of voice is best described in terms of a remodelling of grammatical relations, i. e. constructions where a verbal marker is implied in the redefinition of semantic roles of arguments.

9. For more details on co-participative voices in Wolof, see Creissels and Voisin (2008).

10. Naturally reciprocal events are events that are either necessarily (e.g. 'meet'), or else very frequently (e.g. 'fight', 'kiss') semantically reciprocal (Kemmer 1993: 102).

11. Wolof is an "and-language" in the terminology of Stassen (2000). In its vernacular varieties, the coordination of noun phrases in subject function is impossible (in urban variety, probably due to the influence of French, this kind of coordination is attested). Thus, if the speaker wants to present the participants in reciprocal actions as distinct entities, the best construction is to introduce the second participant into a prepositional phrase $a k \sim a g$.

12. The suffix -andoo results from the grammaticalization of -ànd-u-e 'go.with-MEDIOPASSIVE-e'.

13. For Lichtenberk, the link between reciprocal function and these others situations is what he calls "plurality of relations":

"There is plurality of relations in an overall situation (event, state, etc.) if what can be considered to be basically one and the same relation holds more than once either between one or more participants and the event / state they are involved in, or between the relevant entities." (Lichtenberk 2000: 34)

14. As Payne and Barshi (1999: 9-10) note

"For the External Possessive Relation to assume a transitive subject relation is extremely rare cross-linguistically, and even where it does occur [...], it may mostly surface with rather stative transitive predicates." 


\section{References}

Baker, Mark C.

1999 External possession in Mohawk: Body parts, incorportion, and argument structure. In External possession, Doris L. Payne and I. Barshi (eds.), 293323. Amsterdam/Philadelphia: Benjamins.

Bassène, Alain-Christian

2006 Description du diola-banjal (Sénégal). Thèse de 3e cycle, Université Lumière - Lyon II, Département Sciences du Langage.

Chapell, Hilary

1999 The Double Unaccusative Construction in Sinitic Languages. In External possession, Doris L. Payne and I. Barshi (eds.), 195-228. Amsterdam/Philadelphia: Benjamins.

Church, Eric

1981 Le système verbal du wolof. Dakar: Université Cheikh Anta Diop de Dakar.

Creissels, Denis and Voisin(-Nouguier), Sylvie

2008 The verbal suffixes of Wolof coding valency changes and the notion of coparticipation. In Reciprocals and Reflexives: cross-linguistic and theoretical explorations, Ekkehard König and Volker Gast (eds.), 289-306. Berlin / New York: Mouton de Gruyter.

Diouf, Jean-Léopold

2001 Dictionnaire wolof. Tokyo: Ilcaa.

Fal, Arame, Rosine Santos and Jean Léonce Doneux 1990 Dictionnaire français-wolof. Paris: Karthala.

Frajzyngier, Zygmunt and Traci S. Curl (eds.)

2000 Reciprocals: forms and functions. Amsterdam/Philadelphia: Benjamins.

Gunji, Takao

1987 Japanese phrase structure grammar: A unification-based approach. Dordrecht: Reidel.

Kesteloot, Lilyan and Bassirou Dieng

1989 Du tieddo au talibé. Dakar: Agence de la coopération culturelle et technique, IFAN.

Kesteloot, Lilyan and Cherif Mbodj

$1983 \quad$ Contes et Mythes Wolof. Dakar: Les nouvelles éditions africaines.

Kitagawa, Y. and S. Y. Kuroda

1992 Passive in Japanese. Manuscript. Indiana University and University of California, San Diego.

Labatut, Roger

1982 La phrase peule et ses transformations. Thèse d'état, Paris III. Atelier de reproduction des thèses. Université de Lille III.

Lichtenberk, František

2000 Reciprocals without reflexives. In Reciprocals: forms and functions, Zygmunt Frajzyngier and Traci S. Curl (eds.), 31-62. Amsterdam/Philadelphia: Benjamins. 
Martin, Samuel E.

1959 Essential Japanese: An introduction to the Standard Colloquial Language. Tokyo: Tuttle.

Payne, Doris L. and I. Barshi

1999 External Possesion: What, Where, How, and Why. In External possession, Doris L. Payne, and I. Barshi (eds.), 3-29. Amsterdam/Philadelphia: Benjamins.

Perlmutter, David and Paul Postal

1984 The 1-advancement exclusiveness law. In studies in relational grammar, David Perlmutter and C. Rosen (eds.), 81-125. Chicago: University of Chicago Press.

Sapir, J. David

1965 A grammar of Diola-Fogny: A language spoken in the Basse-Casamance region of Senegal. London: Cambridge University Press.

Shibatani, M. and P. Pardeshi

2001 The Causative Continuum. In The Grammar of Causation and Interpersonal Manipulation, Masayoshi Shibatani (ed.), 85-126. Amsterdam/Philadelphia: Benjamins.

Stassen, Leon

$2000 \quad$ And-languages and with-languages. Linguistic Typology 4: 1-54.

Timoc-Bardy, Romana

1996 Appartenance implicite vs. appartenance explicite en roumain. Faits de langues 7: 241-250.

Velázquez-Castillo, Maura

1999 Body-part EP constructions: A cognitive / functional analysis. In External possession, Doris L. Payne and I. Barshi (eds.), 77-107. Amsterdam/Philadelphia: Benjamins.

Voisin (Nouguier), Sylvie

2002 Relations entre fonctions syntaxiques et fonctions sémantiques en wolof. Thèse de 3e cycle, Université Lumière Lyon II, Département de Sciences du Langage.

Zavala, Roberto

1999 External possession in Oluta Popoluca (Mixean). In External possession, Doris L. Payne and I. Barshi (eds.), 339-372. Amsterdam / Philadelphia: Benjamins. 